\title{
シンポジウム I.
}

\section{病 原 ビブリオ オ \\ 司会 藤 野 恒 三 郎 \\ 大阪大学微生物病研究所}

このシンポジウムの司会は, 福見秀雄博士が担当され ることになつていましたが，御本人が急に外国出張され たため，占部会長の指示により，私が代行することにな りました。

ビブリオ233) と言う術語の意味する内容は，1964 年に 大きく変動したと言わ韹ばなりません。その要点を紹介 します。

Leeuwenhoek（1632 1723）が顕微的な微少生物に小 さな動物との意味で Animacula と命名しましたが，こ の Animacula を Linne(1707 1778)の方法によつて分 類を試みた Müller(1730 1784)は，1773 年に Vibrio 属をはじめて作り，4種がその中にふくまれることにな りました。

これが「Vibrio」が学問の対象になつた最初でありま す。要するに動物界の一属としてVibrio は誕生したの であります。

今日の細菌分類学にみられるVibrio は, 当然のこと ながら植物界の一員であつて, 現在の動物界にはVibrio はなくなつています。

Müller の提案したVibrio 属中の 4 種は, 今日では 他の属に移されてしまつていて, Vibrio Müller 1773 は 空家同然であるはずなのに，Bergey's manual110第7版 によればVibrio comma を代表種として以下種が位置 を与えられています。

1) Vibrio Müller は 100 年以上動物界に掠いて使用 されたことがない。

2) 国際動物命名規約 23 条によれば 50 年以上動物学 文献において senior synonym として用いられたことの ない動物名は忘れられた名 nomen oblitum と考えられ るべきである。

3） 100 余年間，細菌学に扔いてVibrio は広く承認 された属名として確立してきているとの理由をあげて， Hugh(1964) はVibrio Pacini 1854 を, type species Vibrio cholerae Pacini 1854 といっしょに nominia generum conservanda の eist に入れることを提案した
のでした。

また同時に Vibrio cholerae neotype strain として National Collection of Type Cultures (NCTC) strain 8021, American Type Culture Collection (ATCC) strain (14035)をも提案したのでした。

この Hugh 提案が judicial commission に扔いて審 議・投票の結果, 承認公表されました。

1884 年5)* Koch はインドのカルカッタに赴き, 確か に初めてコレラ菌の純培養をとつて，その性状を明らか にしたのでありますが, Koch は Kommabacillus と言 う通俗語を終始用いて，それより 30 年前に出ている学 名 Vibrio cholerae Pacini 1854 を用いてません， Koch はコレラに関する予備知識をもたず，Pacini の与えた 学名を知らずにエジプトに赴いたのであります。

イタリアの Treuisan は, コレラの病原菌の最初の記 載者は Koch にあらずして Pacini であると説いた最初 の人であります。

かくして一つの学術語 Vibrio が最初は 1773 年動物 学的 Vibrio として誕生し，そのまま植物界に入れられ ていましたが，植物学・細菌学的にVibrio を用いてい た Pacini の論文価值を認めて, 1964 年以来植物学・細 菌学的Vibrio の誕生は 1854 年であり,命名者は Pacini であるとの判決が出ている事情を諒解していただきたい のであります。

もう一つ，Vibrio は男装の麗人であつたこと，その ことの日本での発見者は川喜田愛郎教授であるのです。

1965 年 12 月 17 日, 日本細菌学会理事会において川 喜田教授の説明があつたのです。1）手元にあるラテン 語辞書をひいてみても Vibrio はのつていない。(これ には私も同感)。2) Vibrio parahaemolyficus と男性 扱いしているが，1958 年出版4) の国際細菌命名規約の Annotation には, Vibrio はfeminine となつている, と。

調べてみると，なるほど指摘通り p. 118 Annotations では feminine となつています。 
そこでもう一度 Bergey's manual の第7版 (1957)を 調べてみると，34 種のVibrio 中で，それを女性扱いし ている命名者は 2 名だけ, 残りは男性か不明かでありま す。勿論 M. L. mas. n. とありまして「中世ラテン語 男性名詞」と明記してあるのです。

何故に, 1957 年からわずか 1 年後に Bergey's manual 第 7 版のこの項が修正されて 1958 年の annotation にお いて「女性」としなければならなかつたのか，手元には 何の資料もありません。

この annotation にある「Vibrio は女性」は Müller の Vibrio を指すのでありまが, 1965 年以後の Pacini

のVibrio をも拘束するのか？ 私はイタリアの知人に Pacini 論文中の Vibrio は男性か女性かの調查を依頼し ましたが，残念ながら今日までに返事を入手していませ ん。問題は Pacini 論文によつて解決するものと思いま す。また Bergey's manual 第 8 版の出版準備が現在進 行中でありますが，その中でどう扱われているか興味ふ かいものです。

坂崎利一博士日く, 国際細菌命名規約の番人をもつて 任じている Buchanan は parahaemolyficus について 何むいつてこないところをみると，あれほどの人でも気 づいていないののでしよう。と。

ビブリオと言ら術語に少々こだわりすぎましたが，コ レラ菌の問題は, 古くて新しい研究題目であり, 腸炎ビ ブリオは全くのニューフェースであつて，ともに多くの 方々が興味ある成果をあげておられるテーマでありま す。できるだけ多くの研究者に解説を願らことは理想で はあるが不可能なために，会長と福見博士によつて，公
表されている通り，残念ながら 4 人の方によつて話題が 提供されることになりました。

* 1883 年エジプトからのコッホ報告の中にコレラ病 原菌のことは少々書かれているが具体的でない。1884年 7 月 26 日夕 6 時からひらかれた会議記録には, コレテ 菌形態集落外観が明確に記されている。

\section{文献}

1) Breed, R. S., Murray, E. G. D. \& Smith, N. R. : Bergeys manual of determinative bateriology, Williams \& Wilkins Co., Baltimore, 7 th ed., 1957.

2) Buchanan, R. E. : Conservation of Vibrio Pacini 1854 as a bacterial generic name, conservation of Vibrio cholerae pacini 1854 as the nomenclatural type species; Intl. Bull. Bact. Nomen. Tax., 15, 185-186, 1965.

3) Hugh, R. : The Proposed conservation of the generic name Vibrio Pacini and designation of the neotype strain of Vibrio cholerae Pacini 1854 ; Intl. Bull. Bact. Nomen. Tax., 14, 87101, 1964.

4) International Code of Nomenclature of bacteria and Virus, Iowa State College Press, Iowa, U.S.A. 1958.

5) Koch, R. : DieC onferenz zur Erörterung der Cholerafrage, I. : Erster Sitzungstag. Deutsche Medizinische Wochenschrift., 10, 499-507, 1884.

6) The Editorial Board of the International Committee on Bacteriological Nomenclature. International Code of Nomenclature of Bacteria and Viruses, Bacteriological Code, 1958.

\section{1. 腸炎ビブリオのファージ}

○仲西寿男, 前馬健治, 寺本忠司, 飯田豊 神戸市衛生研究所

目的 : 腸炎ビブリオファージ， 3 株の諸性状を比較検 討すること。3株のファージは患者由来の No. 12, 海 水由来の No. 14 抢よび溶原菌由来の No. 6 である。

方法 : ファージ分離に用いた指示菌は坂崎の○および Kの代表株を主とした。溶菌斑の観察および計数は平板 重層法でおこない，寒天培地の 食塩濃度を $0.5 \%$ とす る。ファージの増殖は $0.5 \% \mathrm{NaCl}$ 加ブイヨンでおこ なつた。菌そのものの培養は固形, 液体培地とも食塩濃 度を $3 \%$ とする。
ファージを濃縮またはより精製する場合は 35.000 $40.000 \mathrm{rpm}, 1$ 時間の超遠心を行ない，ついで透析す る。必要に応じてはさらに $\mathrm{CsCl}$ 濃度勾配䞦心法によっ て分画する。ファージの再浮游は $\mathrm{M} / 15$ 燐酸緩しよう液 または M/100 Tris 緩しょう液でおこなら。

ファージの核酸の抽出は, ファージを DNase と R Nase で処理後, Hershey の方法にしたがつた。核酸が DNA か RNA かは過塩素酸で $90^{\circ} \mathrm{C}, 15$ 分処理した後 Diphenylamine および Orcinol 反応をおこなつてきめ た。

ファージの超音波処理は $20 \mathrm{kc}$ でおこなつた。紫外線 照射はナショナル GL-10 管球で $50 \mathrm{~cm}$ の距離からおこ なった。

成績：（1）ファージは患者糞便 27 検体から 1 株, 海 
水 50 検体から 2 株，菌株からは多数分離できたが，例 えば 0 代表株 12 により 7 株分離した。下水・溜水 43 検 体, 正常人糞便 282 検体からは分離できなかつた。

（2）溶原菌の UV 照射および mitomycin C 処理に よる誘発は成功しなかつた。

（3）増殖における収量は No. 12 および 14 では $10^{9}$ $10^{10} \mathrm{ml}$ 程度であるが，No. 6 は常により高く，1011/ $\mathrm{ml}$ であつた。ブイヨン培地の食塩濃度を $3 \%$ とすると収量 が低い。

（4） $\mathrm{CsCl}$ 溶液の密度勾配遠心法によると No. 12, 14 および 6 の比重はおのおの $1.530,1.480$ および 1.315 であつた。

(5) ファージの形態 : No. 12 と No. 14 は頭部と尾部 を認め, 頭部の輪かくは正六角形で最大直経がおのおの $60 \mathrm{~m} \mu$ と $80 \mathrm{~m} \mu$, 尾部は長さが $15 \mathrm{~m} \mu$ と $35 \mathrm{~m} \mu$ であつ て, 何れも根部の幅が大きく, 先端は小さくなる。No. 12 は根部に突起を認める。No. 14 は先端に 3 本の 25 $30 \mathrm{~m} \mu$ の線維をもち, 線維の未端は 3 叉となる(Tripod) No. 6 は線状ファージである。

(6) 3 つのファージの宿主域はそれぞれ異なる。他の ビブリオ 29 株, Photobacterium 6 株のうちで, Photobacterium sepia の 1 株のみが No. 14 によつて溶菌さ れた。

（7）交叉中和試験によると，3つのファージは血清学 的にそれぞれ異なる。なお，K抗原型の異なる菌株から 分離したファージNo. 9 抢よび 10 は No. 6 の抗血清 で中和された。

（8） $20 \mathrm{kc}$ の音波で 3 分処理すると，No. 12 および 14 の活性は約 $10^{-1}$ および $10^{-2}$ 低下するが，No. 6 は 10-4 低下し, 前二者よりも感受性が高かつた。

（9）紫外線に対しては No. 12 および 14 は one hit curve を描いて, No. 6 は multi hit curve を描いて活 性が低下する。

(10) $60^{\circ} \mathrm{C}$ 加熱によつて, No. 12 および 14 の活性は first order kinetics に従つて低下する。No. 6 の活性は $60^{\circ} \mathrm{C}, 80$ 分加熱でも低下せず, $90^{\circ} \mathrm{C}$ および $100^{\circ} \mathrm{C}, 15$ 分加熱で約 $10^{-1}$ および 10-2 低下した。

(11) No. 14 および 6 の核酸は共に DNA である。 No. 14 の DNA は 2 本鎖であつて, その $\mathrm{Tm}$ は $80^{\circ} \mathrm{C}$ と $90^{\circ} \mathrm{C}$ の間にある。

\section{附議武谷 健二 (九大細菌)}

御報告の No. 6 ファージはその形態, 耐熱性, 超音波 抵抗力その他の差においてわれわれが緑膿菌について得 ている Pf ファージによく似ている。Pf ファージは 12
\%の Single strand DNA を含んでいる。なお，両フォ 一ジの異同，近縁性については抗血清を交換して互に検 討したい。

大腸菌の線維状ファージは male-specific, であり, Pf はそうではないが host range が狭いが，No. 6 はどう ですか。

回答仲西 寿男 (神戸衛研)

No. 6 の fibrous な phage の宿主域は, 患者由来の 腸炎ビブリオ 70 株を検定株として用いた場合, No. 12 , No. 14 にくらべて広い。また male specificity について は未検討である。

\section{2. 腸炎ビブリオの抗原性に関する研究}

\author{
三輪谷俊夫 \\ 大阪大学微生物病研究所
}

腸炎ビブリオの抗原性に関する研究をふり返つてみる と, 滝川, 我妻拉よび小菅らの初期の業績に続いて, 坂 崎ら, 大城, 大森らの報告がある。腸炎ビブリオの血清 学的分類法として厚生省・腸炎ビブリオ性食中毒検查要 領にO群別法と K抗原型別法の二方法が示されている。 昭和 37 年に初めてこれらが提示されて以来, 毎年変更 があり，O群別法に関しては抗O血清の凝集価があがり にくく, かつ群相互間の類属反応が強くでるために現在 ではもつぱらK抗原型別法のみが実用に供せられてい る。しかし，この型別法も次々と新らしいK抗原が発見 され，追加されつつあるのが現状である。

われわれは腸炎ビブリオ EB 101 および各O群パイロ ット菌株より抽出し, 部分的に精製した可溶性抗原 $\mathrm{A}$ を 解析して, 類属反応のない群特異性抗 $\mathrm{O}$ 血清の作製と同 時に腸炎ビブリオに広く共通する抗原物質の特異性とそ の分布について行なつた成績をのべた。

I）実験材料および方法

使用した菌株, 各O群パイロット菌株の部分的精製可 溶性抗原Aの抽出精製法および抗血清の作り方について は, 第 37 ・ 38 回日本細菌学会総会において発表したの で省略する。

II）実験成績および考察

(1) 抗 EB 101(A)-(EB 101 の部分的精製抗原 $\mathrm{A}$ の抗血清。以下これに準じる。一一おひび抗O-1 (A)を 用いて EB 101，O群パイロット株 O-1 O-12 および他 種ビブリオより抽出した抗原との間にゲル内沈降反応を 行ならと，EB 101 および O-1〜O-10 との間に明確な一 本の共通沈降線が.認められたが，O-11，O-12 および他 
種ビブリオには認められない。また兵庫県衛研，滝川よ り分与をらけた腸炎ビブリオ O-1 O-10 群の菌株につ いて調へると，この共通沈降線Aは 103 株中 79 株（77 \%)に認められた。

（2）抗 O-1. (A)を用いて生菌凝集反応を行なうと O1 O-10 は 160 倍〜2.560 倍のH凝集を示すが，O-11， O-12 および他種ビブリオは凝集を示さない。

（3）加熱死菌を用いた凝集反応では抗 O-1（A）に対し て O- 1 群は 640 2.560 倍までO凝集を示すが，O- 1 群 以外の 127 株および他種ビブリオは全く凝集を示さな 、。抗 O-1 (A) と同様，抗 O-2 (A) 抗 O-5 (A) までは強 、群特異性を示したが，抗 O-6(A) 以下は他群との交叉 凝集が認められた。この成績は坂崎らが提示した $\mathrm{O}$ 群別 の妥当性を裹付けるものである。

(4) 抗 O-1(A)を O- 2 パイロット株の生菌で吸収す ると, 前述した共通沈降線 $\mathrm{A}$ 示さなくなり, O- 1 群 の生菌との間にH凝集も認められなくなるが，O-1 群 の加熱死菌との間の特異的な $\mathrm{O}$ 凝集価は変らない。また O-1の加熱死菌によつて吸収した抗 O-1(A) O-1の 生菌に対して末吸収のものと同程度のH凝集を示し, 共 通沈降線 $\mathrm{A}$ も認められる。

(5) 免疫電気泳動法により O-1のA物質は主にH抗 原であるが，群特異性 $\mathrm{O}$ 抗原および $\mathrm{K}-1$ 抗原も含まれ ていることがわかつた。

今後, 生物学的性状汃らみて V. alginolyticus と確認 された菌株を集めて, 生物型と血清型の関連性を明らか にするっもりである。

(共同研究者: 岡田正, 西宗広子, 田村俊秀, 安田純 一)

\section{3. コレラ菌の Hemolysin Destructive Fac- tor (HDF)-特に病原性に関連して}

○和 気 朗, 山本, 実, 小河 秀正 国立予防衛生研究所細菌 I 部, 病理部

エルトール・コレラ流行より分離された株が数年前は 溶血性を示し，近年は示さなくなつた。また溶血株を液 体培地に長時間培養すると, 特に振蕰条件下で培地中の 溶血素力価が低下するので, hemolysin destructive enzyme の存在が想定された。(Feeley ら，1963)。

私達は液体培地中に溶血株を培養し, 遠心上清や濾液 を溶血素液 $(\mathrm{HL})$ とし，その完全溶血を示す 最高稀䣋液 で試料を段階稀釈, $37^{\circ} \mathrm{C} 2$ 時間放置後 $1 \%$ ヒツジ赤血 球を等量加え, $37^{\circ} \mathrm{C}$ に 2 時間, $5^{\circ} \mathrm{C}$ に一夜抒いて溶血
反応が阻止される最高稀䣋度を力価とする方法で溶血素 阻止因子の存在を確認し, Hemolysin-destructive factor (HDF) と命名した。

1) HDF の産生と性質： $500 \mathrm{cc}$ の容器中 $100 \mathrm{cc}$ の Syncase (Finkelstein 1964) 培地に被検株を接種, $37^{\circ} \mathrm{C}$ 毎分 112 往復振盪培養 18 時間という一定方式培養の遠 心上清中の HDF 力価を被検株の HDF 産生能とした。 溶血性エルトール型, 非溶血性エルトール型, 古典型と もに産生能を示す株と示さない株があり, rugose 相の 株は産生能がなく, 産生能と Kappa-phage 溶原性の有 無との関係はなかつた。重症患者分離菌と保菌者分離菌 では前者が後者よりも高い産生能を示さなかつた。患者 から直接採取したライス・ウォータ一便, 仔ウサギにお ける実験コレラの腸管貯溜液中に HDF 活性が測定さ れ, 特に前者で高力価で, 回復期患者便の食塩水抽出液 中には測定されなかつたが，この活性が宿主由来である 可能性を考慮すべきである。菌の HDF 産生は使用培 地の組成によつて相違し, heart infusion broth は特に 高力価を与える。HDF の産生は菌発育の 対数期停止期 の境界加ら急速に増加し, 20 時間以後は緩徐に増加す る。部分精製 $\mathrm{HDF}$ は $\mathrm{pH} 5.0 \sim 9.0$ の領域で安定で, $37^{\circ} \mathrm{C}$ で 3 日間安定であるが, $100^{\circ} \mathrm{C} 30$ 分加熱で不活化 し, $0.2 \%$ ホルマリン, $37^{\circ} \mathrm{C} 3$ 日間の条件で安定であ つた。ウサギを免疫すれば中和抗体産生の傾向を示し た。培養上清の $0.3 \sim 0.5$ 硫安分画中に沈澱, 透析膜内 に残り $105,000 \mathrm{G} 1$ 時間遠心上清中に残り，この分画 はマウス仔ウサギ腸管に出血膨隆傾向の強い毒性を示 す。(2) コレラ病原性との関連 : コレラ菌の産生する生 物因子と病原性との関係を遂一明らかにしてゆくことは コレラ病理発生解明の一接近法である。菌の HDF 産 生能と病原性との関連をみる目的で $2 つ$ 試みをおこな つた。（i）組織培養細胞に対する作用。エルトール型 16 株, 古典型 9 株の $10^{8} / \mathrm{cc}$ 液一滴を七ト腸管由来 Henle $1 \mathrm{~N}$ 株, HeLa S 3 株組織培養に加えると菌は細胞内に 侵入せず, 株の HDF 産生能には無関係にエルトール 型は全株が $2 \sim 7$ 時間以内に激しい細胞障碍作用をおこ す一方，古典型は全株 7 時間まで細胞障害作用をおうさ す，この方法は両型を区別する指標にはなるが病原性試 験には適さないことが分つた。(ii) Dutta 試験による比 較, 生後 $9 \sim 14$ 日の仔ウ开ギ 20 匹を用い $\mathrm{HDF}$ 産生能 の高い 5 株をウサギ 8 匹，産生能の低い 5 株をウサギ 6 匹，産生能の認められない 5 株をウサギ 6 匹の腸管内に $10^{6} \sim 10^{8}$ 個注入したところ, すべてのウサギが下痢や腸 管膨隆のコレラ様症状を示し, 注入した菌株の HDF 産 
生能の程度とは関係なくDutta の下麻因子の存在が示 された。しかし平均死亡日は各群 1.1 日，1.8 日，2.3 日であり，HDF と病原性とはなんらかの関連がありう る。その際ウサギ腸管の組織標本にお打る形態的変化は 概して僅少で，変化の範囲，程度に差があるが，主とし て小腸下部に扝そらく水腫によると思われる䋐毛の膨化 と充血があり，粘膜上皮の変性剝離，好中球反応はほと んぞ見られない。HDF 産生株接種例では粘膜から粘膜 下織，時に墏膜面に出血があるので HDF の病因意義 （生物学的意義）に注後検討の余地がある。

\section{4. エルトールコレラ菌ファージの研究}

○神 中寬, 霜鳥 翔一 九州大学医学部細菌学教室

1）エルトールコレラ菌における溶原性

最近数年間，セレ心゙スにはじまって東南アジア各地で 流行しているコレラの病原菌がいわゆるエルトールビブ リオであることは明らかである。これらの菌は，生化学 的，血清学的性状に打いて古典的エルトール菌と区別で きないが，特定のアジアコレラ菌(H 218 株)を溶菌する ようなファージを産生する点でことなつている。われわ れはその区別によつて，病原性との関連においてエルト ールコレラ菌を「セレベス型」と「古典ウーボン型」と にわかつことを提唱し，またこれらのファージが溶菌域 や血清学的性状で共通の性質を示すことから，便宜上 「ん(カッパ)型ファージ」と呼ぶことにした。

$\kappa$ 型ファージは，最近の流行株の大部分で陽性である がまれにそれを有しないもの，継代中に失われたもの があり，またフィリッピンで分離，保存された菌株の中 にも少数に型ファージを持たないものが見出された。こ れらの多くは $\kappa$ 型ファージに感受性があり，また両び溶 原化することも可能であつたので，継代中，ある小はそ れ以前にプロファージを失なつたものと考えられる。

セレベス型エルトールコレラ菌を液体培地に培養する と, 菌数の約 $10^{-3}$ 程度に $\kappa$ 型ファージが 産生される。 プラックは濁つた外観を呈するが中に少数の clear plaque mutant を混ずる。宿主域はきわめて狭いが， H 218 の他少数のアジアコレラ菌も感受性があつた。電子 顕微鏡的には 450 550 $の$ の頭部と, 800 1000 ̊̊ 150 〜200 凡の尾部とからなり，収縮性の尾䩗を有すること が示された。

2）UV およびマイトマイシン C (MC)による誘発 このファージは，UV および MC によつて容易に誘
発できる。15W 殺菌登を用いて，90 cm の距離から， 液層の厚さ $0.8 \mathrm{~mm}$ の菌液を照射した場合, ファージ量 は 15 20 秒で最高となつた。30 秒照射の場合，収量は やや低いが，誘発率 $96.5 \%$ となり，対照の 約 $10^{4}$ 倍の ファージを生じた。

$\mathrm{MC}$ による誘発は，振とう培養の場合， $0.5 \mu \mathrm{g} / \mathrm{ml}$, 静 置培養の場合 $0.05 \mu \mathrm{g} / \mathrm{ml}$ 前後でファージ量は 最大とな つたが，誘発率は UV に比して低いと考えられ，産生 量も対照の $10^{3}$ 倍程度に留まつた。

3）早期診断への応用

前述のとおり，殆んどすべてのエルトールコレラ菌に は本ファージが伴なつているので保菌者, 患者の検索に さいして, 菌の検出と平行してファージの検出を行らこ とができるが，判定に要する時閒は分離培養よりも短か く感度もむしろ高いことがわかつた。アルカリ性ペプト ン水増菌数時間後, TCBS 培地に 分離培養を行うと同 時に, SM $(100 \mu \mathrm{g} / \mathrm{ml})$ 含有培地上の SM 耐性 H 218 株 にスポット，溶菌の有無を検する。完全な同定のために は，抗血清による中和試験，あるいは $\kappa$ 型ファー洏性 H 218 株に対する溶菌の有無を検する。

この方法をフイリッピンで実際に保菌者の検索に用い たところ，菌の検出とファージの検出はよく一致し，乙 かも治療などにより菌の消失した場合にもなおファージ は陽性である場合もあり，保菌者の検出にきわめて有用 な方法であると考えられる。

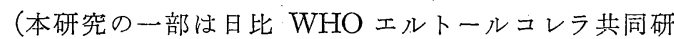
究の一環として行われた。共同研究者：武谷健二, 中山 雍子，押方浩子，飯田恭子，天児和啺）

\section{5. ビブリオの分類に関する研究}

\section{坂 崎 利一 \\ 国立予防衛生研究所}

Bergey's Manual の第7版には，genus Vibrio の中 に 34 species が記載されているが，そ机らは単に形態学 的特性だけで分類されたものが多く, International Subcommittee on the Taxonomy of the Vibrio で決定さ れた genus Vibrio の定義により，確実にビブリオとみ なされるものは，コレラ菌 (V. comma は V. cholerae と改められる)，V. proteus を含めて数種のものにすぎ ないので，新しい見地からこれらを再整理する必要があ る。わたくしのこのテーマに対する研究は Subcommittee の目的にそつて行なわれており，いままでのところ ではつぎの三つの主題，すなわち1）コレラ菌とエルト 
ールコレラ菌との分類学的関係，2）いわゆるNAG ビ ブリオおよびいままで単に Vibrio spp. として未命名の まま保存されている菌の分類学上の位置；3）腸炎ビブ リオに類似する一連の菌の分類; が対象とされている。

菌の分類の手法に法きめられた約束はないとはいえ， 現在その基礎となつているものには，系統発生にのつと つて characterization を重視する Kauffmannism, すべ ての性状を同一価值とし，数学的に処置して similarity を求める Adansonism とがあり，また最近では同一 genus のものはその DNA の GC \%によつて 合致性を 求めるやり方が提案されている。しかし，そのいずれに も一長一短があり，理想的にはそれら三者のいずれでも 満足できる分類でなければならない。この意味におい て, わたくしはビブリオの分類学的研究を, 以上の三手 法を併用して行なつた。その結論はつぎのとおりであ る。

1. コレラ菌とエルトールコレラ菌とは, 本来溶血性 の有無で区分されたすので，のちになつて，その他に アセトイン産生性, ポリミキシンBに対する感受性, Muckerjee のファージIVに対する感受性などにも相違が あることが報告されている。しかし，両菌の閒には移行 型がかなりあつて，これらの性状の相違が本質的なもの とはみなされない。Adansonian classification では両者 のS (similarity) value は $80 \%$ 以上である。したがつ て，両者を別の species とする理由はまつたくなく，エ ルトール菌を V. cholerae biotype eltor とした Hugh の提案が強く支持される。

2. いわゆる NAG ビブリオといわれるものには， 生化学的に大別して 2 群があり, 両者間の $\mathrm{S}$ value は 70 \%以下である。その一つの群の V. cholerae との関 係は，大部分が $\mathrm{S}$ value $90 \%$ 以上で，生化学的特性も V. cholerae に一致し, また GC \%が V. cholerae と 同じ $47 \%$ である点から，Vibrio として分類されるが， 他の一様のものは生化学的に genus Aeromonas の特性 をもち，その GC \%は61で，従来からいわれる Aeromonas formicans に一致する。

3. Hugh は V. cholerae の定義に Gardner の O-1 抗原をもつことをあげ，したがつてこの species をコレ ラ菌にのみ限定しているが, 本来抗原的手法は species 以下の分類に用いられるべきものである。前述のように NAG ビブリオおよび V. proteus の生物学的性状はほ とんどコレラ菌に一致し, S value は $90 \%$ 以上で，し たがつてこれらの菌は当然 V. cholerae の中に分類さ れなければならない。わたくしたちは，すでに NAGビ
ブリオの中に 10 数種の $\mathrm{O}$ 抗原群をみており, コレラ菌 は V. cholerae 中の一O群をして扱われるべきもので あることを強調したい。

4. わたくしたちの分類命名した V. parahaemolyticus と V. alginolyticus とは，いずれも生物学的特性， GC \%, S value で，それぞれ genus Vibrio 中の独立 した位置を与えるべきことが再確認された。

5. V. costicolus についても，それが genus Vibrio 中の一 species であることを確認した。

6. V. ichthyodermis, V. anguillarum. および V. piscium var. japonicus は, 同じ species に分類される のが至当なようである。しかし，それらの GC \%はい ずれもビブリオと同じ 40 数\% であるが，生物学性状で は V. cholerae とは異なる点が多く，S value は70\% 以下で示される。したがつて，これらの魚類病原菌は， ビブリオとは別個の genus の位置が与えられなければ ならない。

7. 以前, “病原性好塩菌生物型 $3 ”$ といわれた菌に は二つの生物型があり，その一つは genus Vibrio 中の 独立した species とみなされるが，他の一つは前記の V. ichthyodermis と同類の菌のようである。

8. Photobacterium 中, $\mathrm{Ph}$. sepia および $\mathrm{Ph}$. harveyi は，いずれの点からみても両者をあわせて, genus Vibrio 中の一 species におくべきことが確認された。 $\mathrm{Ph}$. albensis と $\mathrm{Ph}$. pierantonii については, またじゆ ら分な検討がなされていない。

附議

藤野恒三郎 (阪大微研)

1） NAG Vibrio が表の中に 2 種ありましたが，こ れらの Vibrio 出所に特徴や違いがありましようか?

2) Vibrio の Subcommittee で, Vibrio 属の外へ出 されるものは, 別の属の Subcommittee で受けとめて 検討されるでしようか?

回答坂崎 利一（予研）

1. Vibrio からはずされた菌の命名について，他の 機関にゆだねる責任は Subcommittee にはない。

2. NAG ビブリオの 2 種の出所には相違はない。い ずれも患者, 接触者, 水などから検出される。

\section{シンボのまとめ}

司会者 藤野恒三郎 (阪大微研)

占部会長と福見博士の御協議によつて，5人の方が決 定されました。 5 人とも今までに継続して御研究の方で ありまして，誠に興味ある成果を御発表いただき，関係 者としてお礼申します。 
選ばれた題目がバライテイに富んだものでありますの で，討論の結果をまとめると言つた性質のものではあり ません。ここで，強いて申しますならば，5人のどなた
の研究も現在までよりも, 今後が楽しみであると感じま したのは, 私独りではないと存じます, 今後一層の発展 を期されて本学会に報告されることをお願い致します。

\section{シンポジウム II.}

\section{抗 : 酸 菌 の 分 類 \\ 司会者 堀 三 津 夫}

はじめに

周知のように抗酸菌はすでは分類されているが， Bergey の分類表は，抗酸菌の培養性状，いろいろの動 物に対する病原性, などの生物学的性状を主な根拠とし て分類されたものである。しかしながら近年にいたつて 抗酸菌をこのような分類法で分類することが果して適確 であるかといらことに多くの疑問が提起されてきた。

純料分類学的な立場からの問題はしばらくおくとし て，医学的な面から 1，2の問題をとりあげてみると，

その 1 つはイソニコチン酸ヒドラチッド(INH) に強い 耐性を示す抗酸菌の 問題である。INH 高耐性菌はその 増殖速度が抢そいものが多く，またカタラーゼ，ペルオ キシダーゼ活性は極度に減弱ないしは消失し, さらに多 くの場合モルモットなどの実験動物に対する病原性が低 下することはよく知られた事実である。人型菌からえら れた INH 高耐性菌を，その起源をしらずに，これを人 型菌と同定することは現存の分類法では必ずしも容易で ない。

第 2 はいわゆる非定型抗酸菌の問題である。1950 年 頃から臨床的に肺結核症との鑑別がきわめて困難な疾患 からその病因菌として定型的な人型結核菌とは性質をこ とにする抗酸菌が分離されて, 日本では非定型抗酸菌と 呼称され，アメリカでは Unclassified Mycobacteria (UCM) として総括されている。UCM は Runyon によ つてその培養性状の差異から, I 群 : Photochromogen;

II 群 : Scotochromogen; III群 : Nonphotochromogen; IV群 : Rapid Grower; の 4 群に群別されているが，こ れらの UCM, ことに亚群の UCM 多くのものと既分 類の島型菌, あるいはIV群のあるものと既分類の $\mathrm{M}$. fortuitum との鑑別はきわめて困難である。
このような問題から，世界各国で抗酸菌の再分類の必 要性が強く認識され，要望されているのが現状である。

以上の上うな situation に私共が扔かれていることを まずご理解願つた上で，各演者の講演にはいりたい。し かしその講演内容は抗酸菌の分類といらことを頭におき ながら現在どのような研究が行なわれているか，という ことであって，本シンポジウムのテーマ「抗酸菌の分 類」をそのままとりあげたものではなく，むしろ抗酸菌 の鑑別, 同定の研究がおもなものであることをあらかじ めご了承願いたい。

\section{1. 抗酸菌の示す生理学的性状を中心に}

佐 藤 直行

国立予防衛生研究所結核部

いわゆる同定のために諸種の抗酸菌を観察してきたも のが，抗酸菌の分類といら表題のもとで意見をのべる場 合に，いかなる考え方に立脚して，これに相対するとい うことが，最も重要な点と思われた。それで，具体的例 として現在まで国内に追試確認成績の多い，Bönicke の いわゆる biochemical classification の表をとりあげ，今 日の問題となつている, 未分類抗酸菌について, 菌種の 確立，命名などの点で，演者自身は矛盾混乱におち入つ ていると考えている，二三の点に批判的考察を加えた。

さらに演者らの観察成績として, 発育温度域のみを示 し，それをもとにして文献上の知見とともに考察してみ た。

（実験方法）小川培地上の 3-14 日培養菌を用いて， ホモジナイザー法で菌液を作り，比濁法で $1 \mathrm{mg} / \mathrm{ml}$ に 調整した。これを $10^{-1} \sim 10^{-5} \mathrm{mg} / \mathrm{ml}$ に希勫してそれぞれ の希釈菌液を $0.1 \mathrm{ml}$ ずつ小川培地に接種し， 22,25 , 
$30 ， 37 ， 42 ， 45$ および $52^{\circ} \mathrm{C}$ の各温度で培養した。発育 のはやい菌株では 6 週間培養で, 発育のおそい菌株では 14 週間培養で観察を打ち切つた。

（実験成績） 発育の括そい抗酸菌の発育温度域 $\left({ }^{\circ} \mathrm{C}\right)$ を総括すると，つぎのようになつた。すなわち，ヒト型 菌 173 株, ウシ型菌 24 株, ネズミ型菌 2 株では, す心 て $30^{\circ} \sim 37^{\circ}$ であつた。M. ulcerans では $25^{\circ} \sim 30^{\circ}$, 卜 リ型菌 20 株では $25^{\circ} \sim 42^{\circ}$ であつた。また M. kansasii 11 株では $25^{\circ} \sim 37^{\circ}$, Runyon II 群の 22 株では $22^{\circ} \sim 37^{\circ}$ であつた。しかし, Runyon III群 36 株では $22^{\circ} \sim 37^{\circ}$ の 範囲惊共通であつたが， $42^{\circ} ， 45^{\circ}$ における発育の有無と 多少とから，三ないし四区分ができるようであつた。 Runyon 四群のこれら四つの代表株とトリ型菌 Kirchberg 株の発育曲線を比較して, Kirchberg 株では $22^{\circ}$ 培 養で 14 週間してほぼ full growth に達するのに対し て, Runyon 畐群の 4 株では， $22^{\circ}$ 培養で 6 週間してほ ぼ full growth に達することを示した。

すなわち Runyon III群の発育温度域の不均一性, ト リ型菌と皿群との間の差を認めた。

つぎに発育のはやい抗酸菌 113 株については，発育温 度域の上限を目標にしてつぎの六つの区分を行なつた。 すなわち，I． $30^{\circ}$ まで発育するもの，II． $37^{\circ}$ である程 度発育するもの， III. $37^{\circ}$ まで発育するもの，IV． $42^{\circ}$ ま で発育するもの，V． $45^{\circ}$ まで発育するもの，VI． $52^{\circ}$ ま で発育するもの，である。

区分 I. II. に入るものは, すべて魚由来のものであ り，I. に入るものは M. platypoecilus, M. piscium, M. salmonifilum で，前二者は光発色性陽性であつた。 II. に入るものは, M. marinum と M. balnei(3 株)で あり，ともに光発色性陽性であつた。区分亚に入るもの は 24 株あり,集葉の型と色からさらに三つに分けられる が，菌種として独立したものはなかつた。区分Vには， M. fortuitum ( 8 株) と蛙慈慶株を代表とする, R 型白色 の 30 株が入っていた。区分Vには M. smegmatis を代 表株とする 24 椎と， M. butyricum を代表株とする 15 株が入り，区分VIには M. phlei ( 4 株)が入つていた。

さらに，発育曲線を比較して，220 培養における $\mathrm{M}$. phlei の発育速度は, M. smegmatis, M. fortuitum にく らべて，著しくおそいことが注目された。

以上の発育のおそいものと, はやいものとに分けて, 抗酸菌の発育温度域を検討し, それを生理学的性状の表 現として総括し，区分して示した。莯酸菌同定上のかぎ そして利用しうる一性状であることは，周知のことであ るが、これによつて抗酸菌の分類ができたとはもちろん
考えてもいない。

（共同研究者，高橋宏）

\section{2. 抗酸菌のファージタイピング}

\section{徳 永徹 \\ 国立予防衛生研究所結核部}

抗酸菌をつァージ感受性によつて分類しようとする試 みはかなり古くから行われてきたが，一昨年より WHO がその研究課題の一つとしてとりあげ, 主として方法論 に関して, 目下第 2 次共同実験が進行中である。以下演 者らの成績を中心として, タイピング研究の現状と問題 点, 将来の研究方向などにつき述べることとする。

(1) 方法論：いわゆる $1 \mathrm{RTD}$ スポット法の採用, 血 清学的性状によるタイピングファージ保存, など演者ら の年来の主張が国際的にも認められ, WHO 分科会で む取入れられつつある。定量的研究にはプラークカウン 卜法，タイピングには RTD スポット法といら方式が国 内でも定式化したとといえよう。その場合問題となるの は培地である。Redmond は小川培地についてマラカイ ドグリーシ濃度が濃過ぎる点に多少の難色を示した。そ こで演者は $0 \sim 400 \mu \mathrm{g} / \mathrm{ml}$ のマラカイドグリーンを含む 数種類の 1 \%小川培地と, WHO の RVA 24 培地(Dubos 寒天培地を一層 rich にしたもの)を用いて EOP の 比較を行なつたが，5\%テルルサンカリを平板上に流す 方法の併用により1\%小川培地が充分実用に供し得るこ とを確認した。但し定量的な研究用には RVA 培地が 種々の点で秀れている。

（2）発育の速い抗酸菌のタイピング：全体を 6 グルー プに分ける分類表を考案した。その結果は，発育温度域 や糖分解能るよる分類とかなり良く一致した。手技の簡 単なこと, 結果の解明なことなどの故に, ファージタイ ピングは発育の速い抗酸菌の分類に最も有用な方法の一 つと言うことができよう。

なお BK 4 ファージは従来タイピングができなかつた M. fortuitum と呼ばれる菌群をいくつかに分け得る可 能性をもつことが見出された。

(3) 発育のおそい抗酸菌のタイピング : DS 6 A, GS $4 \mathrm{E}, \mathrm{L} 1$ などのファージを用いて, ヒト型結核菌, ウシ 型菌および photochromogens を同定できるようになつ た。トリ型菌とnonphotochromogens, scotochromogens の 3 者は一般にファージ感受性がなく，目下のところこ の 3 者をファージによつて分類することはできない。し かし最近これらに属する菌の中に，たとえばトリ型菌の の CDCA 1, nonphotochromogens $の 121326$, scotoc- 
hromogens の P 32 などの菌株に 感受性をもつファージ が得られた。このような適応ファージを将来数多く追加 することができれば，従来分類が困難であつた菌群の夕 イピングが可能となるかも知れない。

ファージタイピングがすでに実用化されているチフス 菌やブドウ球菌の場合, タイピングの対象となる菌は病 原菌に限られて抒り, 疫学的診断法として用いられてい る。抗酸菌の場合もその例にはならえば, チフス菌の $\mathrm{Vi}$ 抗原, ブドウ球菌のコアグラーゼテストに相当する 何らかの方法でまずヒトの病原菌を選別し，しかるのち ファージでその中をタイピングするといらことになる。 このよらなヒト結核菌のサブタイピングは，他に手段が 見られぬためファージに固有の課題であろら。この点 は 1963 年ローマで開かれた抗酸菌ファージシンポジウ ムで演者が強調したところであるが，その後 Baess， Bates, 杉田らによつてこの点の検討が行われつつある。 演者らも，さきに武谷らが今村株について感受性に差が あることを指摘した B 1 ファージ，杉田らのK1ファー ジ，Baess の BK 1 ファージを含む数種のファージを用 い，RVA 24 培地上でのプラークカウント法による正確 な感受性テストを行なつたところ，B 1 ファージは H37 $\mathrm{Rv}, \mathrm{H} 37 \mathrm{Ra}$ ，青山 B に強い感受性を有し， $\mathrm{H}_{2}$ ，今村弱毒 株，奄美強毒株に対しては EOP が約 2 オーダー落ちる ことを見出した。これらの菌の INH 耐性株の感受性は 原株の感受性と変りはなかつた。また K 1 ファージは RVA 培地上では明らかな差が認められなかつたが，小 川培地上では $\mathrm{H} 37 \mathrm{Rv}$ および青山B 株が $\mathrm{H}_{2}$ に比べ杉田 らの指摘のごとく 1 ない 2 オーダー感受性が 低かつ た。DS 6 A感受性はいずれの菌でも等しかつた。この ようにヒト結核菌の中にもその感受性を注意深くテスト すれば，少くともいくつかのファージパターンが存在す ることは明らかであるが，乙かし簡便でかつ再現性の高 い方法として確立するまでにはなお将来検討を要する問 題が少くない。しかし Redmond らが主として未分類抗 酸菌の適応ファージを得る方向に努力している現時点で 日本の研究者はある程度組織的に, 主としてヒト型結核 菌のサブタイピングといら方面で, 貢献を心掛けるのが 望ましいのではないかと考える。

回答德永徹（予研・結核部）

1），特別に異議質問はありません。

\section{3. ツベルクリン反応特異性および生化学的 性状による抗酸菌の分離}

\author{
中山雍子 \\ 九州大学医学部細菌学教室
}

我々の教室では, ツベルクリン反応特異性による抗酸 菌の分類, ならびに生化学的性状による分類法を研究し てきたが，これに更に新しく試みた esterase と catalase の zymogram を比較する方法を加えて報告する。

I．ツベルクリン反応特異性による分類

精製ツ蛋白 $\pi$ を用いてモルモットで皮内反応を行い。 発赤を比較する方法であります。(1)人型菌と牛型菌とは きわめて近似した特異性を示し, 鼠型菌むこれらによく 似ていた。(2M. kansasii は人型にやや似た均一の特異 性を示した。(3)鳥型菌と Nonchromogens は殆んど区別 出来ない。又, Non. 群は, 調べた範囲内ではほぼ均一 の特異性を示した。(4)Scotochromogens 群は少くとも2 つ以上の群にわけられる。(5). fortuitum は M. phlei, M. smegmatis とは全く異なる特異性を示し, 従来, 本 邦で分離継代されていた蛙慈恵, 人非 $5, \mathrm{~B} 16$ 株は M. fortuitum と同じ特異性を示した。 (6M. runyonii は, M. fortuitum とは明らかに異なり，本邦分離の山本, 佐藤株は，M. runyonii と同じ特異性を示した。これら の結果は，いずれも生化学的性状における(1)人型菌と鼠 型菌, 鳥型菌と Nonchromogens 間の類似性, (2)Scotochromogens の多様性(3)外国株，日本株で区別出来ない 事(4)人型，M. kansasii 等，すでに species として確立 された菌群内ではいずれも，かなり homogeneous であ る事，等の諸点とよく一致するものであると思われる。 又, 今回は M. fortuitum と M. runyonii の判別に有 用と思われる生化学的性状につき報告する。すなはち, Bojalil らは, M. runyonii の species name を提唱し, M. fortuitum との 鑑別点として, ニニチンアミダーゼ 6 時閒反応陽性, クエン酸塩利用能陰性をあげているの であるが, その他に, 耐熱性一酸性フォスファターゼ活 性 (一), アラントイン分解 $(-)$, 硝酸塩還元 $(-)$ 等の諸 点でもこの両者を鑑別する事が出来た。

次いで，抗酸菌で，一般に強い活性のみられる esterase および catalase の電気泳動 パターンを比較する事 によつて，各 species 間の質的な差違の一面をとらえる 事が出来れば分類にもかなり役立ち得るのではないかと 考穴実験を行なつた結果，かなり species specific なパ ターンを得たので，あわせて 報告する。まず esterase: 
では(1)人型，牛型は同一パターンで 3 本の bands が検 出されたが人型の 7 株中 1 株では，1 本の band にやや ずれがみられた。(2)鳥型では 7 株中 7 株が同一パターン を示し，6本の bands が検出された。(3M. kansasii では， 9 株中 9 株が同一パターンで 2 本の bands が検 出された。(4) M. fortuitum 14 株では株によつてやや差 がみられるが，概ね 6 本の bands がみられた。(5M. runyonii では，佐藤株等の示すパターン (6株) と M. runyonii.\# 380，481，518 等の示すパターン( 5 株)の 2 つの型に別れた。いずれも，ほぼ 6 本の bands が検出 された。(6M. phlei では 11 株中全株に同位置の 3 本の bands を検出しえた。(7)M. smegmatis では 12 株中, 全 株に共通な 4 本の bands とややばらつきのみられる 2 本の bands がみられた。 (8) Scotochromogens, Nonchromogens は，かなり heterogeneous であつたが，これら の細分類に役立ち得るのではないかと思われる結果も得

、ているが，いずれも今後の研究にまつところが多い。

catalase でも，実験を行なつた範囲内では species specific な位置にその活性がみられ大部分の 菌種は 1 本 の強い band を示した。又，この方法では，M. fortuitum と M. runyonii, 鳥型菌と Nonchromogens の間に 差はみられなかつた。

以上，ツベルクリン反応特異性ならびに生化学的性状 が，菌の分類ならびに同定によく役立ちらる事を，我々 の教室で得たデータについて報告した。M. runyonii は 末だ，人に病原性を示す rapid-growers の species とし て広く認められていない様であるが，一つの重要な species としてここに今後考慮される必要があるのでは ないかと思われる。

又, 新しく試みた esterase および catalase zymogram 法でも，かなり species specific な結果が得られここの 方法も分類の一助になりらるのではないかと思われる。

\section{4. $\alpha, \beta$ 抗原の各種ミコバクテリヤにおけ る分布とその意義について}

\author{
福 井 良 雄 \\ 大阪大学微生物病研究所
}

近年 immunodiffusion 法が開発された結果，この方 法によつて得られる抗原構造のスペクトラムは, 細菌分 類に扔ける一つの有力な示標となりつつある。しかし， ミコバクテリヤに拉けるこの方面の研究は末だその緒に ついたばかりで, 現在少数の研究者たち（Parlett and Youmans, Lind, Castelnuovo ら)の手によつて, 粗抗原と
その抗血清を用いた研究からそのスペクトラムの一部が ようやく明らかにされかけた状態である。いらまでもな く,このような抗原構造を詳細, かつ明確に把握するた めには, 従来の研究のような, 単に粗抗原そのままの分 析のみならず構成抗原の一つ一つを分離し，それらに対 する特異抗血清を作つて, それらを指標にして研究をす すめることが是非必要である。我々は結核菌抗原構成お よび抗原特異性など結核菌蛋白抗原の基礎的性状を明ら かにする目的で, 毒力人型結核菌 H37Rv 株の培養濾液 から, 蛋白抗原の分離, 精製を行なつた結果, 高度に純 化された 2 種類の蛋白抗原 $(\alpha$ および $\beta)$ とそれぞれの特 異抗血清をうることに成功し，ここに始めて単一指標抗 原と抗血清による抗原分析が可能となつた。今回は，以 上の $\alpha, \beta$ 抗原が人型結核菌 H37Rv 以外のミコバクテ リヤにどのように分布しているか，またその分布像がミ コバクテリヤの血清学的分類における指標としてどの程 度の意義をもつかを明らかにするために, 各種ミコバク テリヤ 120 株について解析した結果を報告する。その結 果要約すれば, 試供株は $\alpha, \beta$ の分布と, 免疫化学的性 状の差異によつて次の 4 グループに大別される。I . $\alpha$, $\beta$ 共に存在する株 : INH 耐性株を除くすべての人型, 牛型結核菌および M. microti，II. $\alpha$ が存在するが $\beta$ 細 胞外に検出出来ない株 : ここにはすべての INH 耐性人 型, 牛型結核菌が入る。これらは次の Subgroup に分け ることが出来る。1） $\beta$ の全く認められないもの（高度耐 性菌)。2） $\beta$ が菌体内にのみ検出出来るもの（低度耐性 菌)。III $\beta$ は認められず， $\alpha$ の部分共通抗原 $(\mathrm{crm})$ の存在 する株 : これらは更に $\mathrm{crm}$ の免疫化学的差異により次 の Subgroup に分けることが出来る。1）P8型のもの (M. kansasii の一部が含まれる，2）avium 型のもの（す べての M. avium と M. paratuberculosis, M. balnei, M. ulcerans および 23 株の unclassified mycobacteria, 更にソ癩菌 ( 8 株) が入る)。IV, $\alpha, \beta$ 共に検出出来なか つた株: M. phlei, M. smegmatis など雑菌性ミコバク テリヤおよび 22 株の unclassified mycobacteria が含ま れる。

以上の結果は，ミコバクテリヤが $\alpha$ とその crm 抽 び $\beta$ 抗原の分布像によつて, 分類されること, またこの Serotype が従来の biotype による分類とは，さほぼ矛 盾してない可能性を示すものである。さらに又この結果 は従来のごとき抗原の有無による解析のみならず, 共通 抗原の免疫化学的差異が少くとも，ミコバクテリヤで は，その血清学的分類の有力な指標となりうることを強 く示唆するものである。現在更に各 Species から共通 
抗原および特異抗原の単雑を行ない，詳細な抗原分析を 進めている。

(共同研究者, 米田正彦, 山之内孝尚, 森竜男)

回答

中山 雍子（九州大・細菌）

福井先生 私も，御指摘の点が問題であると思つてお りますが，もつと数多くあたつてみるとか，人工的な変 異株について検討してみるとかする事によつて，更にこ の方法が使えるものであるか否かをはつきりさせる事が 出来るのではないかと思っております。又，多くの band が検出される株の場合は, 必ず検出される何本か の band のみを目安にする事も考えられると思つており ます。

\section{5. 螢光抗体法ならびに凝集反応による抗酸 菌の血清学的分類について}

\author{
斎 藤 肇 \\ 広島大学医学部細菌学教室
}

研究目的：凝集反応ならびに螢光抗体法を採用してい わゆる非定型抗酸菌の分類ないし同定について追究す る。

方法 : 凝集反応一トリ型菌計 37 株ならびに Nonphotochromogens(以下 Nonphoto.) 計 131 株(Battey 菌 60株 動物系菌 54 株おうよ゙土㗒系菌 17 株）の総計 161 株の 7 $\mathrm{H}-10$ 寒天培地上発育菌より調製した一定濃度の均等菌 液を抗原とし,トリ型菌 3 株, M. kansasii 1 株, Scotochromogens 4 株ならびに Nonphoto. 22 株よりの抗家免 血清との間の反応をWidal 反応に準じておこなう。螢 光抗体法一直接法には卵培地上発育菌の滅菌蒸溜水浮遊 液よりの塗抹標本を $65^{\circ} \mathrm{C}, 2$ 時間固定後, $37^{\circ} \mathrm{C}, 30$ 分 間染色する。又間接法には $7 \mathrm{H}-9$ 培液中 7 日培養菌より の塗抹標本を $65^{\circ} \mathrm{C}, 30$ 分固定し, 第 1 次反応は $37^{\circ} \mathrm{C}$, 45 分, 又第 2 次反応は 8 倍稀勫羊抗家鬼標識抗体で $37^{\circ}$ C, 30 分間染色する。鏡検には光源に高圧水銀灯 HBO200 を使用し, フィルター系としては Leitz の単眼 SM 顕微鏡では 1 次フィルターBG 12 と 2 次フィルターOG 1 との組合せのもとに, 又 Zeiss の単眼 GFL 顕微鏡 では 1 次フィルターBG 12 と 2 次フィルター 53 との 組合せのものにおこなう。

成績 : 凝集反応一1）トリ型菌は 2 つの Major groups と 1 つの Minor group のいずれかに分類され，Nonphoto. 血清群に群別された菌株は皆無であつた。他方, Nonphoto. ではトリ型菌血清群に分類された少数株 (7 \%）を除いては Battey 菌と動物系菌とを問わずいずれ
\& Nonphoto. 血清群の 7 つの Major groups と 15 の Minor groups ならびに Scotochromogen の1つの血清 群のいずれかに分類された。即ち，凝集反忘はトリ型菌 -Group III Nonphoto. Complex を解析する上にある程 度迄役立つ。2) Battey 菌では大多数の 菌株が Nonphoto. 群の I, III, IVおよびIXに属したのに対して動物系 菌では II, VI, VIIIおよびIXに属した。3）土壤系菌では 明らかな Major groups はないようであつたが，17株 中 7 株は Battey 菌の Major groups のIIIはIVに属し た。螢光抗体法一1）演者の方法によれば直接法でも間 接法でも R 型菌と $\mathrm{S}$ 型菌とを問わず intact の抗酸菌細 胞をそのままで染色することか可能であつた。2）ヒト 型結核菌計 40 株, M. kansasii 計 $40^{\prime}$ 株およびチモテー 菌計 16 株についての 交叉反応は直接法ではこれらの各 菌種よりの標識抗体の, 又間接法では 1 次反応に用いる 抗家兔血清の一定稀釈液を用いることによつてともに各 菌種に特異的反応が期待出来た。3）トリ型菌, 非定型 抗酸菌および雑菌性抗酸菌間の交叉反応では Nonphoto. P 23 株と抗スメグマ菌標識抗体との間においてそれと 同種標識抗体との間にみられたと同程度の強い反応がみ られたが，これを除いたいずれの菌株においてもそれら よりの標識抗体との間に最強營光がみられ, 異種抗原と の間の反応は全くみられないか，みられたものにおいて もその程度はより弱かつた。4) M. kansasii と M. marinum (M. balnei) とは螢光抗体直接法によつて 鑑別 可能であつた。5）螢光抗体直接法によるトリ型菌およ び Battey 菌の亜群別は凝集反応によるそれと一致し た。6）家族内感染例より分離され, Engbaek により トリ型菌と同定されたる菌株は螢光抗体直接法によりい ずれも Nonphoto. II群に亜群別され, Nonphoto. 所属 菌株であることが示唆された。7）大府荘束村博士より 分与をうけたトリ型菌ならびに Adansonian classification によつてこれど鑑別不能の Battey 菌計 11 株の 螢 光抗体直接法による分類は, 仮に既分類が正しいと仮定 した場合その適中率は 11 株中 8 株（73％) であつた。 8) M. runyonii のうち $\mathrm{S}$ 型菌の 380 株, 山本 $\mathrm{S} 1$ 株 および佐藤株はいずれも M. fortuitum とは明らかにこ となつた抗原性を有し, 又同 $\mathrm{R}$ 型菌の 481 株, 518 株お よび $335 \mathrm{R}$ 株ではこれらともことなつた抗原性を有する もののよらであつた。

考察：凝集反応ならびに螢光抗体法も亦いわゆる非定 型抗酸菌の分類ないし同定上他の方法と併せ用いられる べき 1 手技となりらるものと思われる。 


\section{おわりに}

司会者堀 三律夫

各演者の講演は以上であるが，その内容を簡単にとり まとめると，

抗酸菌の分類法として，ぞちらかといえば今日まであ まりとりあげられていなかつた。ファージ，タイピン グ ; 抗原抗体反応による鑑別, 同定, 酵素活性の差異, などを利用した鑑別，同定，などの研究が各演者によつ て試みられ，既存の生物学的性状にもとづく分類におお きく矛盾することなくこれらの成績が組みこめることが 明らかにされた。ただし UCM のIII群に属する抗酸菌 と鳥型との鑑別はきわめて困難であり，また UCM の III群, IV 群の抗酸菌はそれぞれいくつかの Subgroup に 分けた方がよいのではないか，といらことは各演者のほ ぼ一致した成績である。

討論は時間の関係で司会者が問題点をしぼつたため に,

各演者の講演内容については演者間にあまり活潑な討
論は行なわれなかつた．ただ司会者として一言ふれたい ことは，たとえばツベルクリン反応の特異性，あるいは 螢光抗体法を利用した抗酸菌の鑑別，同定の研究では， 研究の性質も抗酸菌のもつ共通抗原の問題があらかじめ 十分にチェックされることが望ましい。

第 2 亿本シンポジアムのテーマである分類について は，医学的な立場から，鳥型菌と UCM との鑑別の必 要性, その意義, 将来の研究方向, などが討論された。

ここに司会者として結論をのべると，私共は抗酸菌の 分類を将来の目標として, まづ抗酸菌の鑑別, 同定の研 究に邁進せねばならない。今日の各演者の研究をとりあ げても，それぞれの分野で今後に研究されねばならない 問題が山積しているように思われる。したがうて今後ま すます研究が進展し，それぞれの成果が列記されてはじ めて分類が考えられるべきであろら。

抗酸菌の分類を, 純粋に分類学的な立場からとりあげ るか，それとも医学的な面の比重を重視してとりあつか らか，はおのづから別個の問題として討議されねばなら ない。 以上

\section{シンポジアムＩII.}

\section{微 生 物 細 胞 の 構 築}

座長武谷健 二

微生物細胞の構築といらテーマを会長から与えられた わけでありますが, 微生物細胞の各構成要素についてそ れぞれ演者に分担をお願いして, 単に微細構造の形態学 的追求といらことだけでなく, できる丈, 微細構造と化 学組成および機能との関連について話していただきたい と思います。

\section{1. 細菌線毛の構造と機能}

\section{橋 本 雅 一}

東京医科歯科大学微生物学教室

電子顕微鏡の改良とその普及に伴つて, 細菌細胞を含 む微生物微細構造の観察が非常に容易になり, また細菌 の微細構造に関しても多くの知見が報告されるようにな つた。この構造物の一つに線毛 (fimbriae or pili) があ
る。

Anderson(1949), Houwink(1949), Houwink \& van Iterson(1950)らは, Shadow casting method による電顕 像の観察で, 種々のグラム陰性桿菌の菌体表面に鞭毛と は明らかに識別できる微細な線維状の構造を観察した。 このような菌体表面の構造物の存在は, ついで Brinton, Buzzell \& Lauffer(1964), Duguid, Smith, Dempster \& Edmunds(1955)によつて E. coli で確認され，この構 造物の出現と, 古くから認められていた細菌・赤血球凝 集反応(Bacterio-Hemagglutination)の発現との間に密接 な関連があることも指摘されるようになり，この微細構 造と機能についての検討が加えられるようになつてき た。

演者もまた数年来この問題を取上げ，Bacterio-Hemag 
glutination を背景として, 形態学的, 血清学的, 生化 学的, 遺伝学的扝よび生物学的な面から検討を加え, 細 菌線毛の構造と機能について次のような見解に達してい る。

まず，線毛の構造については，形態学的および血清 学的検討から，少なくとも腸内細菌科の 菌属の 線毛は Escherichia-Shigella type, Proteus type および Rettgerella-Serratia type の 3 つの型に分類され，このうち

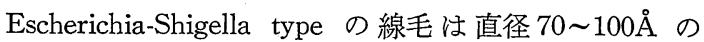
mannose-sensitive (MS) adhesin を凝集因子とし，Proteus type と Rettgerella-Serratia type は直径約 $45 \AA$ の mannose-resistant (MR) adhesin を凝集因子としている。 そして，これらの線毛は lipopolysaccharide を主成分と する subunits が念珠状に配列することによつて構成さ れ, subunits は MS adhesin 型の線毛では密に, MR adhesin 型の線毛ではかなり弛く配列してるいと考えら れる。

上述のような構成をもつそれぞれの型の線毛はその機 能においては遺伝因子の制御を受け，線毛変異を伴つて 代謝過程の変化をきたし，乙かも線毛相ではその強い付 着性によつて変化する環境にす早く適応することによつ て“種の保存と生存”に主要な役割をはたし，またおそ らく自然条件でも起つていると考えられる線汑の伝達に よつて“種の進化”にも役立つているのであろう。

以上の見解に導かれるに至つた実験成績について報告 した。

\section{追加俵 寿太郎（岡山大学微生物）}

El Tor Vibrio に Sheath と Core があり sheath は 甚だ不安定であり, Core は菌体内に通じていて割に安 定である。

鞭毛根部には $200 \mathrm{~m} \mu$ 大の球状顆粒が認められる。

\section{附議吉井 善作 (山口大医微)}

(1) 追加 $\cdots$. 私は B. alvei の Sporemembrane から 出ている Fimbriae の像を得ております。珍しい所見と 思われますので追加致します。

(2) 質問 $\cdots$...Fimbriae と slime layer or capsule と の関係は如何でせうか?

\section{回答橋本 雅一（東京医歯大微生物）}

fimbriae または pili と; slime layer あるいは capsule 形成との間には，形態学的にも機能的にも，なんら関連 を認めておりまません。

$$
\text { 質問. 武谷 健二（九大・細菌） }
$$

Brinton らは線毛の機能に関連して，有線毛菌は酸素 欠乏の cell density の高い環境で特によく増殖するとの
ベているが，その点についてデータあれば御教示願いた い。

\section{回答}

橋本 雅一（東京医歯大微生物）

fimbrial state と non-fimbrial state の間には, $\mathrm{O}_{2}$ uptake の差があるようには思われません。ただ，glucose fermentation にはかなりの差異が認められますが，その 意義についてはまだよく分つておりません。

座長 武 谷 健 二

線毛には演者ののべられた細胞凝集性の普通のものの 外，F-pili あるいは R-pili などの染色体 1 個当り 1 本 しかない特殊のものがあり，核酸の伝達に与かると考え られている点で興味深いが，今回はこれについては時間 がないので取扱わない。

\section{2. 真菌の表面構造とその化学組成}

橋 本 忠 世

徳島大学医学部細菌学教室

われわれは，不完全菌に属し，Geotrichosis の原因菌 として知られる Geotrichum candidum をえらび，そ の菌体構成体の電子顥微鏡的観察と生化学的分析結果を 基礎にして, 真菌一般の細胞学的基本微細構築のモデル をつくりあげる努力をしているが，今回はその細胞壁の 化学組成，とくに形態保持に関与する R 層の局在とその 組成とこの菌の multiple septal pores の形成機序およ びその生物学的意義について報告した。

Sabouraud glucose 固定培地または液体培地にて培養 した Geotrichum candidum グルタールアルデヒド, オスミック酸で二重固定, Epon 包埋後切片をつくり, 硝酸鉛染色を施して観察すると，その細胞壁は部分的に は差があるが，弾力性のある厚さ約 $10 \sim 15 \mathrm{~m} \mu$ の外層 と，それにつづく 30 50 m $\mu$ の中間層，および 100 $150 \mathrm{~m} \mu$ の厚さをもつ内層に区別出来る。

(1) 機械的に分離精製した 細胞壁を $1 \mathrm{~N} \mathrm{NaOH}$ で室 温 $3 \sim 8$ 時間，または $98 \%$ Ethylene diamine で $37^{\circ} \mathrm{C}$ 3 日間処理すると主として中間層が抽出され，その構成 物は S 2.6 程度の単一の大きさを示す主として Galactomannan protein complex である。その他これは小量 の glucose をふくみ水に可溶性, PAS 反応強陽性で陳 旧培地より精製される菌体外多糖体と成分が酷似してい る。このことは菌体外 Trichophytin と Trichophyton mentagrophytes 細胞壁についても同様で 真菌菌体外多 糖体の細胞壁 Origin を示すものと解される。

(2) 更に高温度にて $\left(75 \sim 100^{\circ} \mathrm{C}, 1 \sim 3\right.$ 時間) $1 \sim 3 \mathrm{~N}$ 
$\mathrm{NaOH}$ で抽出される多糖体には上記の多糖体の小量と glucosamine 大量の glucose および traceの uronic acid をふくむ。この処理により最内層の microfibril 網が外 面より透視出来る様になると同時に最外層の elastic layer が脱落する標に思われる。この多梼体は単一でな い可能性が大で水に不溶性，PAS 弱陽性を示す。

(3) 上記処理を経ても細胞壁はなほ十分その rigidity を保持している。これを $1 \mathrm{~N} \mathrm{H}_{2} \mathrm{SO}_{4}$ で $75^{\circ} \sim 100^{\circ} \mathrm{C} 2 \sim$ 6 時間処理すると microfibrils は分散してその上清より は大量の glucose と clutin より由来したと考えられる glucosamine が検出される。この glucan は PAS 染色 陰性，ほとんどアルカリ不溶性でこれが包埋する chitin fibril 綱と共に細胞壁の形態推持に重要な 役割を果して いる。glucan-chitin 層が rigidity 保持に関与している ことはこの菌の protoplast と spheroplast 形成の際上記 各層にみられる変化を観察することにより更に明確に証 明される。すなおち Helix pomatia または Helix peliomphala の腸間消化液㧤よびその分画物を $0.8 \sim 1.0 \mathrm{M}$ $\mathrm{NaCl}$ 浸透圧保護液中で生菌に作用さすと適当な条件下 では protoplast または spheroplast を形成する。この際 常に $\beta-1: 3$ 結合をもつ laminarin および上記第再層の glucan-chitin 層を分解して大量の glucose を遊離する 分画にのみその形成能がみられ, 精製 $\alpha$-amylase, $\beta$-glycosidase, cellulase, lipase, lysozyme, chitinase, 種 々 Proteases (Nagase, Pronase, など) では全く無効で，そ の至適 $\mathrm{pH}$ は laminarin を基質とした $\beta-1: 3$ glucanase のそれと一致する。これらの結果より最内層の glucanchitin 層を真菌の rigid layer と称してよいと思われ る。

この菌の隔壁には直経 $400 \sim 500 \AA$ 前後の 小孔が多数 存在しそれが plasmodesmata と考えられるべき性質の ものであることを切片像で証明した。この成因は生物学 的に興味深いもので, 隔壁形成が外側細胞壁の陌入途中 または末だ末熟な時期にそれに接する細胞質よりの microvilli による貫通とそれにつづいておこる microvilli の先端の隣接細胞質との隔合によつておこると解釈され る。

この機序による plasmadesmata 形成は微生物界はも とより，高等生物にもみられていない新しいもので，更 に詳細な過程を追究中である。

（研究協力者：吉田長之，相良安信，河野道昭）

追加

岩田，和夫（東大細菌）

Candida albicans C-a-13 株を半合成培地にてタンク培 養した菌体を Braunの cell homogenizer にて破壊し，
DNase, RNase, pronase 処理を経て凍結乾燥により白色 粉末状の細胞壁画分を抽出精製した。

本標品のN量は $2 \%$ 前後で，これは細胞壁に固有の蛋 白質に由来するものと考える。本標品でウサギを免疫す る場合，血中抗体価はほとんど上昇しないのに対して， 皮内反応は $10 \gamma$ 程度で陽性を示寸点で，感作原性の主 役を担るうものとみなされる。

なお，本標品のアミノ酸組成，糖構成等の成績につい てもふれた。

回答

橋本 忠世（徳大細菌）

真菌表在性多糖体の抗原性解析は目下 Candida albicans の cell wall を用いて行なつており，免疫学的な 意義は Trichophyton cell wall origin $の$ Trichophytin で代表されるような関係が存在するものと考える。

附議莫一 (大阪市大・細菌)

中等度好塩菌 101 株は細胞壁単独でも特有の低調溶液 中で溶解現象を示す。この溶解により細胞壁は溶解した 残りと直経 100 200 $\mathrm{m} \mu$ の $113 \mathrm{~S}$ Fragment と soluble fraction の 3 つに分れこれらの各 fraction は，糖やアミ ノ糖の薄層クロマトグラフィー, 赤外吸収等の結果何れ も cell wall 由来である。更にこの Fragment に Nagarse, Phospholipase, Lipase 等を作用させると形態上 少しごつ変化は来すが，依然 Fragment の形は保たれ る。この cell wall の Fragmentation は Pseudomonas aeruginosa に EDTA, Lysozyme を作用させた時の様 子とよく似ている。

この様に好塩菌 cell wall での $\mathrm{Na}^{+}$除去による fragmentation は単に好塩菌特有の現象としてみるよりグラ ム陰性菌表面構造の解析への手掛りとなると思い追化し ます。

座長 武 谷 健 二

cell wall の化学組成とその生物学的意義, 特に 免疫 原性との関連については，最近数年間に急速な進歩がみ られているが，今後これらの成果と微細構造の追究とい う形態学的研究とのより密接な結びつきが切に望まれ る。

\section{3. 細菌の細胞質内膜構造}

\section{○.山口 淳二, 福士 主計} 東北大学抗酸菌病研究所

細菌の細胞質内に存する膜構造が，1957 年演者等お よび Zapf により共に抗酸菌で発見され，その切片像が 膜状を呈していたことや，菌体を破壞して得られた顆粒 
画分に呼吸酵素系が濃厚に存在していたことから，mitochondria に相当する構造であろうと推定された。しか し当時の実験技術でこのような構造物だけを純粋にとり 出すことには困難を伴い，その機能についてはつきり結 論づけるまでに至らなかつた。その後このような膜構造 は他の細菌にも広く見出されるようになり，報告者によ つてそれぞれ異つた名称で報告されているが，以下 Fitz-James の命名にならつて mesosome と呼ぶことに する。近年細菌においても細胞化学を電子顕微鏡レベル で行なえるようになつたので，mesosome，の機能を知る 手がかりとして，電顕レベルでの䤉素細胞化学を結核菌 と Bacillus megaterium でこころみた。今回はこれら の成績をもとにして, 細菌の mesosome について考察 を加えてみた。

実験方法 : 人型結核菌 H $37 \mathrm{Ra}$ 株および B. megaerium 8100 株を succinic dehydrogenase の活性をみる ため sodium succinate と tetranitro-blue tetrazolium (TNBT) 或は nitro-blue tetrazolium (NBT) を含む Sedar 等の液に，また cytochrome oxidase の活性をみ るため p-aminodiphenylamine と p-amino-p'-methoxydiphenylamine を含む Burstone の液にそれぞれ浸漬し た。ATPase の活性をみるため glutaraldehyde で前固 定した人型結核菌 H37Ra 株を ATP と硝酸鉛を含んだ Otero-Vilardebó 等の液に，また acid phosphatase の活 性をみるため sodium $\beta$-glycerophosphate と硝酸鉛を含 んだ変法 Gomori の液にそれぞれ浸漬した。このような 細胞化学的処理のあと, $\mathrm{OsO}_{4}$ で固定してから, Epon 包埋切片を作製して電顕で観察した。なお対照として基 質を含まない液，およびそれぞれの酵素の inhibitor を 加えた反応液に浸漬した試料の切片をむあわせて電顕で 観察した。

所見：結核菌と B. megaterium では共に succinic dehydrogenase の活性を示す dense な TNBT 或は N$\mathrm{BT} の$ formazan の沈着が強く mesosome に一致して 認められ，一部細胞質膜にも認められた。小胞状を呈す る mesosome では一般に限界膜よりも内部の小胞に強 く沈着する傾向がみられた。formazan が強く aggregate して沈着していて, mesosome の内部構造を不明瞭にし ている例が少くなかつたが，微細な formazan の粒子が mesosome を構成している膜に一列に配列している例む みられた。又 B. megaterium では NBT の formazan が核に沈着している例も稀に観察された。結核菌と $B$. megaterium に㧍ける cytochrome oxidase の活性を示す dense な反応産物む mesosome に局在して認められ, その
所見は succinic dehydrogenase の活性を示す formazan の沈着と似ていた。

結核菌で ATPase の活性を示す鉛の粒子は mesosome に多数認められるほか, 細胞質膜, 細胞質にも認められ たが，核には認められなかつた。興味ある所見として， mesosome では構成している膜の外側表面に微細な鉛の 粒子が明膫に観察され，一部細胞質膜でもみられた。 acid phosphatase の活性を示す鉛の沈着も ATPase の 場合とほぼ同様の所見であつた。

細胞質内膜構造 (mesosome)のまとめ：(1)mesosome は 細胞質膜が細胞質内部に巻きこんでできたもので，細胞 質膜と連絡している。(2菌分裂時に形成される隔壁とも 密接に連絡している。(3)細胞質内だけでなく，しばしば 核内にもみられる。(4)mesosome には呼吸酵素系の 主要 酵素である succinic dehydrogenase, cytochrome oxidase が局在しているほか ATPase, acid phosphatase なども 存在している。以上の事実から細菌の mesosome は動 物細胞の mitochondria に似た機能や菌分裂時の隔壁形 成に関与する機能を営み,さらに動物細胞の lysosome に似た機能をむ営むことが推定される。

(共同研究者 : 有路文雄)

附議菅 沼惊（京府医大・微生）

細菌の細胞質内膜構造 (mesosome) の特徴はこれが細 胞質膜 (plasma membrane) と連続していることであ る。しかしブドウ球菌の plasma membrane は普通の条 件では cell wall と密接してーつの dense layer を作つ ていると思われる。 mesosome はこの dense layer と連 続して見られることが多い。又一方, mesosome は核に 密接し, 場合によつては mesosome の膜と核の fine fila ment とが連続している如く見られることがある。な㧍， オスミック酸固定を長時間行なつた場合 plasma membrane が cell wall からはなれて三層の unit membrane として観察された。

座長発言武谷健二

細胞質内膜構造 (メゾゾーム) の問題は, 後の胞子形 成の問題とも関連があるので, 共通の話題として綜合討 論のときと取扱います。

\section{Corynebacterium 属の顆粒の細胞化学的 電子顕微鏡的研究}

\author{
川田十三夫 \\ 鳥取大学医学部細菌学教室
}

ジフテリア菌の顆粒として従来異染小体(Polyphosp- 
hate 顆粒)がよく知られているが，演者ら (1965) は陳旧 細胞においてこれまで報告されていない微細顆粒の集合 よりなる特殊な小体を超薄初片において観察し，他の Corynebacterium 属 (C. pyogenes, C. renale, C. xerosis, C. equi など) にもこの小体が出現することを知 つた。今回は主としてジフテリア菌，C. pyogenes にお いて polyphosphate 顆粒とこの特殊な 細胞質内小体を 継時的に電子顕微鏡で観察すると共に細胞化学的検索を 行ない, これら顆粒の出現消失過程, 性状などについて 検討した。

C. diphtheriae C 4 株之 C. pyogenes Daini-Nojo 株 を主として用い, Pope のぶどら糖加塩類基礎培地に振 盪培養, または Löffler 培地, チョコレート寒天に培養 し, 燐タングステン酸によるネガチブ染色法と超薄切片 で電顕的に観察した。ネガチブ染色法は whole cell に おいて顆粒, 細胞質内膜系などの構造, 動態を示し, そ れらの出現率を電顕下で算出し，同時に Laybourn 染 色，Gram 染色による顆粒などと比較検討できる。

ジフテリア菌, C. pyogenes は互い細胞質内の諸構造 は類似し, Pope 液体培地におけるネガチブ染色で次の ような結果が得られた。対数発育初期には比較的小さく (直径 30-100 $\mathrm{m} \mu$ ) 単純な層状小胞状構造を呈する 細胞質 内膜系が多数 ( 1 細胞中に $10 \sim 20$ 以上) 点在し, 培養時 間の経過と共に大きくなり, 定常発育期以後にはその数 は減少するが，かなり陳旧な細胞にも時に残在し，polyphosphate 顆粒の消長とは直接の関係がみられない。対 数発育後期になると電子照射により容易に昇華する円形 の dense な顆粒が $90 \%$ 以上の細胞に出現し，次第にそ の大きさを増してくるが，この顆粒は異染小体と一致す る。この polyphosphate 顆粒は定常期以後は小さくなり 減少するが, この時期に球形で時に周辺不規則な電子線 で比較的昇華され難い電子密度の高い 顆粒（直径 200 $500 \mathrm{~m} \mu)$ が出現し始め, 培養 36 48 時間では 50 75\% の菌にみられる。この顆粒の周辺は正円なものと不規則 なものがあり，また顆粒が less dense な層で取りかこ まれ, さらにその外側に dense な層がみられる場合も ある。この顆粓の出現極大期に Laybourn 染色による 異染小体の出現率は $10 \%$ 以下に減じていることからこ の顆粒は異染性を示さないことがわかる。

またいわゆる“Gram 陽性顆粒体”とも一致しない。 すでに報告したようにこの特殊な細胞質内小体の切片像 では，その芯部は dense な微細顆粒（直径 $5 \sim 10 \mathrm{~m} \mu$ ) の集合よりなり，その周辺はこれら微細顆粒の点在する less dense な中間層とそれら顆粒の集積からなる dense
な外層に取りかこまれているが，芯部のみのものもみら れる。この顆粒は培養の経過と共に電子密度を減じ小さ くなり培養 5 日以後にはその出現率は $5 \%$ 以下になっ た。 $0.01 \%$ 覀テルル酸カリの添加によりこの顆粒の出現 が促進されるが，またすみやかに消失した。Löffler 培 地ではこの顆粒の出現消失の過程がチョコレート寒天の 場合よりもすみやかである。チョコレート寒天では数力 月〜 1年余にわたりこの顆粒が残在し，その直径が $1 \mu$ 以上のものがみられる。

Pope 培地に 15 時間培養の C. pyogenes を蒸留水, 燐酸塩緩衝液中で休止状態におくとこの特殊な顆粒は形 成されず，polyphosphate 顆粒が小さくなり遂には消失 する。特殊な顆粒をもつ菌を新鮮な培地に移すと密度を 減じ消失する。またこの顆粒は蒸留水中で $60^{\circ} \mathrm{C}, 100^{\circ} \mathrm{C}$ 30 分加熱により加水分解され電子密度を 減じる。音波 処理または French pressure cell による細胞破壊後, こ の特殊な顆粒の超遠心分画を試みたが，細胞の破懐と共 にこの大半もこわれるため分画には不成功でその化学的 性状は検討するにいたらなかつた。この顆粒は耐久体そ のものとは考光難く, 環境の悪化した場合に出現する貯 蔵物質と推測される。

(協同研究者 : 井上晃孝)

\section{B. cereus の芽胞形成期の微細構造の 研究}

小 池 聖 淳

九州大学医学部細菌学教室

細菌の芽胞形成は細胞分化の一型であることから，遺 伝学的, 形態学的, 生化学的に種々研究が行われている, われわれは今回「細菌の構築」という観点から, 電子顕 微鏡的に芽胞形成過程を追求し, かつその stadium 毎 のコハク酸脱水素酵素活性の局在場所を Tetranitroblue tetrazoliumを用いて決定した。さらに各種高分子生合 成阻害剂を stadium を追つて, 作用させ, 芽胞形成阻 害の効果を生物学的におよび形態学的に検索した。

1. 芽胞形成過程

用いた菌は B. cereus No. 2 を Foster にしたがって endotrophic sporulation を行わせた, この時の medium. は主として Tris butter pH 7.2である, medium の置 換後， 2 時間ではなお分裂中の菌が見られるが，4 時間 で棒状核，および septa 形成の菌 (Stadium 1), septa 完成のもの (Stad. 2)，6時間では完全に endospore に なるが末だ cortex は出来ていない (Stad. 3) 又 Stad. 2 から 3 への移動形, および spore cell 形成, cortex 
形成の初期 (Stad. 4), が見られる, Stad. 4 までで Fore spore が完成する。 8 時間では outer spore coat の形成 cortex の増大, exosporium の形成が見られ, この時芽 胞原形質が極度に osmophilic になる (Stad. 5)。この状 態を Black spore とよぶ。10 時間では outer spore coat は完成し inner spore coat 以内は無構造状になり, density は低下する (Stad. 6)。もはや spore は完成し 耐熱性をもつ。次にこれが exosporiumをもつたまま free spore になる(Stad. 7)。汃くて，芽胞形成過程は 7 段階に分類できる。

2. コハク酸脱水素酵素活性 (SDH) の局在 endotrophic sporulation を始めて $4 ， 6 ， 8$ 時間目に Sedar の 方法に従つて, Tetranitroblue tetrazolium を用い, SDH 活性部位を電顕的に検索した。Stad. 3 までは SDH active な mesosome により誘導されながら fore spore membrane が endospore の形成えと伸展していくが, この membrane も非常に SDH 活性度が高い。Stad. 4 になると, membrane の SDH 活性は消失し, spore 外 の mesosome の活性が高くなる。Stad. 5 以後では cortex 形成に作用していると思われる inner spore coat 淁した mesosome および形成されつつある outer spore coat に接した mesosome, Exosporium に接した mesosome の活性が高い。以上を要約すると, Fore spore 形成過程と, Spore 成熟過程とでは SDH activity に差があることがわかつた。

\section{3. 各種高分子生合成阻害剂の芽胞形成阻害}

FUDR は endotrophic sporulation 直後の vegetative state の菌は阻害する。committed cell は抑制されない。 Acridine orange $3 \gamma / \mathrm{ml}$ は Stad. 1 までは阻害する。 Mitomycin C $10 \mathrm{r} / \mathrm{ml}$ は Stad. 3 までは抑制されるが, Stad. 3 で mitomycin C の作用をらけると, spore の viability は阻害されるに拘らず， maturation は完成す る。Actinomycin D $10 \mathrm{r} / \mathrm{ml}$ は Fore spore 完成では抑 制出来ない。Chloramphenicol でも同㥞である。2,6dimethoxy phenyl penicillin および cephaloridine は septation を阻害する。penicillin $G$ では, replacement 後の初期では penicillinase を誘発するが, sporangia で は penicillinase を誘発せず抑制的に作用する。

\section{6. 炭疽菌の静止および発芽芽胞の形態につ いて}

\author{
“蜂須賀養 悦 \\ 名古屋市立大学医学部細菌学教室
}

芽胞には exosporium のあるものと,ないものとがあ る。B. anthracis の芽胞には exosporium が存在する。 exosporium は spore coat を包んだうすい膜様の構造と 解されていた。しかしこの exosporium にはその表面に さらに毛髪状の繊細な構造一細毛の存在することがわか つた。細毛の存在については 1964 年 Gerhardt 等が B. cereus の芽胞について報告しているが，その存在が確認 された。炭疽菌の 芽胞の細毛は長さ 約 $720 \AA$, 直径約 $100 \AA$ であるが，その長さは驚くほど一定である。この 細毛漠構造から発生していることが明らかで，Gerhardt 等も述べているように, exosporium は basal membrane と，そ机より発生した細毛とから成立してい る。

静止芽胞においては exosporium と，かなりの空間を おいて内側に spore coat がある。 spore coat は osmiophilic な膜であるが，これは二枚のうすい膜より成つて いる。 spore coat $の$ 内側に cortex がある。cortex は Eponより low density の部分とより dense な部分と から成つているが; cortex material の存在を示してい る。cortex の内側に spore membrane に包まれた core が存在している。

yeast extract および casamino acid の 1 \% 溶液 $1 \mathrm{ml}$ あたり，5 mg の L-alanine および adenosine を含有し た培地 $(\mathrm{pH}$ 7.2) に炭疽菌の芽胞を培養し, 発芽に伴う 形態的変化を調べた。培養 30 分の発芽芽胞は core の 発達のため osmiophilic な spore membrane が spore coat に接近し， cortex の部分が殆んど消失し，あとに 膜様の構造を残す。芽胞全体が大きくなり，でこぼこ のあつた exosporium および spore coat は太く丸く伸 張し, spore membrane に接近した状態となる。培養 2 時間半では, core は young vegetative cell の protoplasm の構造をとり, spore membrane は cell wall の 構造を示し, spore membrane と exosporium の basal membraneとの間には, spore coat (二枚の膜) と cortex の部分につくられた membrane が三層の膜構造となつ て存在する。またあるものは, young vegetative cell が 誕生したため，あとに抜け穀を残している。拔け穀は， exosporium, spore coat および cortex の部分に出来た 
membrane より成立している。young vegetative cell の 出現する形成は，芽胞の一端を破つて現われる。誕生し たばかりの young vegetative cell は棈円形を示してい るが，分裂を行ら頃に，炭疽菌特有の形を示すに至る。

ラットは炭疽菌に対し，かなりの自然抵抗をもつてい る。ラットの腹空に多数の炭疽菌芽胞を接種しても, 芽 胞は殆んど発芽しない。ラットの自然抵抗は芽胞の発芽 を許さないことにその原因があると想像されたので，炭 疽菌芽胞の発芽を促進する L-alanine と adenosine を 各 $5 \mathrm{mg} / \mathrm{ml}$ に含有した溶液 $1 \mathrm{ml}$ を予め腹腔に注射した 後 $5.5 \times 10^{8}$ 個(この 10 倍量の芽胞数でもラットを敝さな い）の芽胞を接種した。発芽は見られたが vegetative cell えの成長が見られなかつた。そこで $1 \%$ \% yeast extract と casamino acid の溶液 $1 \mathrm{ml}$ を予め腹腔に注 射後, 芽胞を接種した。明らかにvegetative cell が見ら れたが、ラットは憼死しなかつた。そこで $1 \%$ yeast extract + casamino acid の溶液 $1 \mathrm{ml}$ あたり $5 \mathrm{mg}$ の割 に L-alanine と adenosine を含有せしめたものを, 予 め $0.5 \mathrm{ml}$ 注射後, 芽胞を接種した。発芽および発芽後 の成長注著明であつた。一方生体側からの溶菌作用も著 明で，その溶解像に特長があつた。すなわちあたかも， cell wall の骨骼のごときリング状の 構造が 重なり合つ た形態のみを残して溶解した。しかし溶解されない vegetative cell も存在し，24 時閒〜 48 時間内にラット は獘死した。マウスにおいては何んら前処置を行なわな くても, 芽胞のみで vegetative cell に成長し, ラット に見られた溶解像もなく，24 時閒内に整した。以上の 成績より，ラットの自然抵抗は芽胞の発芽と発芽後の成 長増殖を許さないことに，その原因があると想像され る。

（共同研究者・小島清秀，佐藤泰山）

追加

川田十三夫（鳥取大医細菌）

(1) Bacillus anthracis の sporulation の初期段階の像 を示した。B. cereus の場合と同様に cytoplasmic membrane の陥入による forespore membrane が形成され る。inner fore spore membrane は spore cytoplasmic membrane になると考えるが, outer fore spore membrane が spore coat の部分図になるという Ohye \& Murell らの説については疑問がある。

(2) Bacillus cereus 3132 株の endotrophic sporulation において 2 時間培養で fore-spore membrane を形成し ている時期に $10 \mu \mathrm{g} / \mathrm{ml}$ の chloramphenicol 添加した場 合この fore spore membrane はそれ以上に develop し ない像を示した。

附議

橋本 忠世（徳大細菌）
Endotrophic sporulation の際は Inoculate した菌数と 形成された spores の数が近くなる様に medium を検討 して autolysis を防ぎ, sporulation process の解折をす ることが大切と思う。

回答小池 (九州大学医学部)

Endotrophic sporulation はお話のごとく, 物質代謝の 面をみる場合には不利であることは解しているが，形態 学的にかなりに Synchronous に材料をとることが出来 る点で, 秀れている, それで inhibitor の作用が無効であ るという点を解折するには何成り慎重に行う必要がある が Endospore formation と Spore maturation の二つの 段階があつて, SDH activity も異るし inhibitor の作用 の仕方も両者の閒で違らことは明らかであると思う。

座長 武 谷 他二

演者らののベたよらに, メジジームは菌の分裂時の, Cross wall 形成や胞子形成に際して重要な役割を果すと 考えられ，また，核にも深い関係をもつており，「菌体 内で何か動きのあるところ必ずメゾゾームあり」といつ てよいと思われる。その意味で, 各演者に共通なこの問 題について一言ううつ意見を伺いたい。

橋本 忠世（徳島大細菌）

mesosome の機能に関して:

obligate anaerobe にも mesosome は存在するので respiratory activity（狭義の）にのみ焦点を合せて解折す ることは危険である。細胞質内の transport や synthesis なども合せて考慮する必要があると思う。

山口 淳二（東北大抗酸菌研）

一口に申しまして，

mesosome は菌体の energy supplyer で, いろいろの 形態をとりながら, 生成流転しているもので, turn over の非常に早い分化の低い一つの organellae であると思 います。

川田十三夫（鳥取大医細菌）

内膜構造は細胞の発育時期によりその形態数などをこ とにするので正常発育における動態をとらえる必要を感 じる。Clostridium, Treponema などの嫌気性微生物に も存在し, その機能は単一でなくかなり多様生に富むと 考えられる。

小池（九州大学医細菌）

Mesosome に関しては，すでに多くの人がいわれてい るように機能的には極めて多様性であり, 一つの機能を 行らものが特定の mesosomeで行われると決まつている のではなくて流動的なものと考えられる。 
司会 武 谷他二

メゾゾームの機能に関しては私も多様なものと考えて いる。進化に伴つて, 真菌や高等生物細胞になると, こ れが恐らくそれぞれリゾゾーム, 小胞体，ミトコンドリ
アなどの独立の小器管に分化していくものであつて, 細 菌においてはなお末分化の原始的な状態に止まつている ものであろうと思われる。 